\title{
RADIOCARBON CONCENTRATION IN ANNUAL TREE RINGS FROM THE SALAMANCA REGION, WESTERN SPAIN
}

\begin{abstract}
Andrzej Z Rakowski ${ }^{1,2,3} \cdot$ Toshio Nakamura ${ }^{4}$ Anna Pazdur ${ }^{2} \cdot$ John Meadows $^{1,5}$
ABSTRACT. Tree-ring samples were taken from a from a pine tree (Pinus pinea) growing in Villar de Peralonso, a rural area $50 \mathrm{~km}$ west of the city of Salamanca, Spain. All samples were processed to extract $\alpha$-cellulose and the radiocarbon concentration in each annual ring was measured using accelerator mass spectrometry (AMS) at the University of Nagoya, Japan. The data set covers a growth period between 1979 and 2006, and represents the concentrations of ${ }^{14} \mathrm{C}$ in a "clean area." The average difference between ${ }^{14} \mathrm{C}$ concentrations in Villar de Peralonso and $\mathrm{NH}$ zone 1 for the period $1979-1999$ is $4.1 \pm 1.3 \%$. A sample was taken to obtain the reference level of ${ }^{14} \mathrm{C}$ for the Iberian Peninsula, for a study of anthropogenic emission of $\mathrm{CO}_{2}$ in urban areas. As part of the initial study, ${ }^{14} \mathrm{C}$ concentration data in tree rings from the city of Valladolid were used to recalculate the fossil fuel component $\left(\mathrm{c}_{\mathrm{foss}}\right)$ using reference data from Villar de Peralonso.
\end{abstract}

\section{INTRODUCTION}

The traditional radiocarbon method, widely used in archaeology and geology for chronological purposes, is also useful in environmental studies. Combustion of fossil fuels such as coal, natural gas, petroleum, etc., in industrial and/or heavily urbanized areas, has increased the carbon dioxide in the atmosphere. The addition of fossil carbon has caused changes in the carbon isotopic composition, in particular, leading to a definite decrease in ${ }^{14} \mathrm{C}$ concentration in atmospheric $\mathrm{CO}_{2}$ and other carbon reservoirs (ocean and terrestrial biosphere), known as the Suess effect (Suess 1955).

Due to the processes of photosynthesis and assimilation of carbon from the air, tree rings (e.g. Muraki et al. 1998, 2001; Rakowski et al. 2008, 2010, 2012), leaves (e.g. McNeely 1994), and other short-lived plant tissues (i.e. Quarta et al. 2007) reflect the changes in ${ }^{14} \mathrm{C}$ concentration in the atmosphere. By measuring ${ }^{14} \mathrm{C}$ concentrations directly in atmospheric $\mathrm{CO}_{2}$ samples and/or biospheric material growing in an industrial and/or urbanized area, where high emission of dead carbon is expected, it is possible to estimate the total emission of fossil-fuel-derived $\mathrm{CO}_{2}$. Based on equations of mass balance (Levin et al. 2003) for $\mathrm{CO}_{2}$ concentration, stable isotopic composition of carbon, and ${ }^{14} \mathrm{C}$ concentration, it is possible to calculate the $\mathrm{CO}_{2}$ concentration associated with fossil fuel emissions into the atmosphere. The procedure uses the differences between ${ }^{14} \mathrm{C}$ concentration and stable isotope composition of carbon observed in a clean area and an industrial or/and urban area.

\section{SAMPLES AND METHODS}

Samples were taken from annual growth rings in pine trees using hollow drills. To obtain sufficient material for accelerator mass spectrometry (AMS) analysis, 3 core samples were taken from each tree and annual growth rings were separated. Each core taken using the hollow drill was $25-30 \mathrm{~cm}$ long and $0.5 \mathrm{~cm}$ in diameter. Samples were washed in distilled water and prepared using the widely used acid-base-acid (ABA) method. Samples were then treated to extract $\alpha$-cellulose from each annual ring using a method described in Green (1963) and Pazdur et al. (2005).

\footnotetext{
${ }^{1}$ Leibniz-Laboratory for Radiometric Dating and Isotope Research, Kiel, Germany.

${ }^{2}$ Institute of Physics, Silesian University of Technology, Gliwice, Poland.

${ }^{3}$ Corresponding author. Email: arakowski@leibniz.uni-kiel.de.

${ }^{4}$ Center for Chronological Research, Nagoya University, Nagoya, Japan.

${ }^{5}$ Centre for Baltic and Scandinavian Archaeology, Stiftung Schleswig-Holsteinische Landesmuseen, Schloss Gottorf, Schleswig, Germany.
}

(C) 2013 by the Arizona Board of Regents on behalf of the University of Arizona Proceedings of the 21st International Radiocarbon Conference edited by A J T Jull \& C Hatté RADIOCARBON, Vol 55, Nr 2-3, 2013, p 1533-1540 


\section{A Z Rakowski et al.}

Alpha-cellulose samples were combined with cupric oxide and sealed into quartz tubes that were subsequently evacuated with a rotary pump. The tubes were then placed in an electric furnace for $2 \mathrm{hr}$ at $850{ }^{\circ} \mathrm{C}$. Carbon dioxide produced from the samples was purified in a glass cryogenic vacuum-line system. Water produced during combustion was removed via a trap containing a mixture of methanol and liquid nitrogen at $170 \mathrm{~K}$. Sulfur compounds were removed with an n-pentane trap cooled to $77 \mathrm{~K}$ by liquid nitrogen. In the next step, the liquid nitrogen is removed and the n-pentane slowly starts to melt. Because of its low sublimation temperature, the $\mathrm{CO}_{2}$ is released, but the sulfur components stay in the trap. Purified $\mathrm{CO}_{2}$ was then condensed in glass tubes using liquid nitrogen.

The prepared $\mathrm{CO}_{2}$ samples were reduced to graphite using iron powder as a catalyst (Kitagawa et al. 1993). The iron powder was prepared in a vacuum line containing hydrogen and heated for about $1 \mathrm{hr}$ at $450{ }^{\circ} \mathrm{C}$. The line was evacuated and $\mathrm{CO}_{2}$ gas was introduced to the iron powder and condensed using liquid nitrogen. Hydrogen was then added and the glass tube was sealed. Reduction was done in an electric oven at $650^{\circ} \mathrm{C}$ for $6 \mathrm{hr}$.

The resulting mixture of graphite and iron powder was dried and pressed into a target holder for AMS ${ }^{14} \mathrm{C}$ measurement with a HVEE 3MV Tandetron AMS system at Nagoya University (Nakamura et al. 2000). Each target was measured for $30 \mathrm{~min}$ in each of 3 analyses. The ${ }^{12} \mathrm{C}^{3+}$ and ${ }^{13} \mathrm{C}^{3+}$ currents were kept at 190 and $200 \mathrm{nA}$, respectively. The typical counting rate for NBS Ox II standard samples for this machine is $\sim 60 \mathrm{cps} .{ }^{14} \mathrm{C}$ contents are reported as ${ }^{14} \mathrm{C}$ in per mil (\%) deviations from the standard sample, with 0.7459 activity of NBS oxalic acid (SRM-4990C) (Stuiver and Polach 1977). Formulas presented in Mook and van der Plicht (1999) were used for age correction and correction for isotopic composition.

\section{RESULTS AND DISCUSSION}

\section{Villar de Peralonso}

Villar de Peralonso $\left(41^{\circ} 2^{\prime} \mathrm{N}, 6^{\circ} 13^{\prime} \mathrm{W}, 820 \mathrm{~m}\right.$ asl, Figure 1) is a municipality located in the Tierra de Ledesma region in the province of Salamanca, Castile and León, Spain. According to the Instituto Nacional de Estadística (www.ine.es), the municipality has a population of 278 inhabitants. The monthly average temperature for each month of the year is higher than $0{ }^{\circ} \mathrm{C}$ (Vitigudino station, 18 $\mathrm{km}$ west of Villar de Peralonso, World Weather Online 2012), which allows us to assume that the growing period for a pine tree can be extended for most of the year.

Differences in $\Delta^{14} \mathrm{C}$ concentration in tree rings from Villar de Peralonso and average ${ }^{14} \mathrm{C}$ concentration in Northern Hemisphere zone 1 (NH zone 1; Hua and Barbetti 2004) are presented in Figure 2. The average difference between ${ }^{14} \mathrm{C}$ concentrations in Villar de Peralonso and $\mathrm{NH}$ zone 1 for the period $1979-1999$ is $4.1 \pm 1.3 \%$. An average year-to-year decrease of $8.8 \pm 1.9 \%$ per year for ${ }^{14} \mathrm{C}$ concentration in tree rings from Villar de Peralonso was obtained for the period 1979-2006 and is similar to the $10.2 \pm 1.3 \%$ per year for NH zone 1 (1979-1999, Hua and Barbetti 2004) and $8.3 \pm$ 1.7\% per year (1983-2003) obtained for Niepołomice (southern Poland, Rakowski et al. 2012). An exponential curve was fitted to the observed data for the period 1979-2006 to determine long-term changes in ${ }^{14} \mathrm{C}$ concentration in the atmosphere and biosphere, giving the correlation coefficient $r^{2}$ $=0.986$ ( 0.996 for $\mathrm{NH}$ zone 1 ; Hua and Barbetti 2004). These analyses provide a time constant for decay of $16.6 \pm 0.3 \mathrm{yr}$ for tree-ring data from Villar de Peralonso and $15.9 \pm 0.2 \mathrm{yr}$ for $\mathrm{NH}$ zone 1 data (Hua and Barbetti 2004) and are similar to the $15.9 \pm 0.3 \mathrm{yr}$ estimate for Niepolomice (Rakowski et al. 2012). 


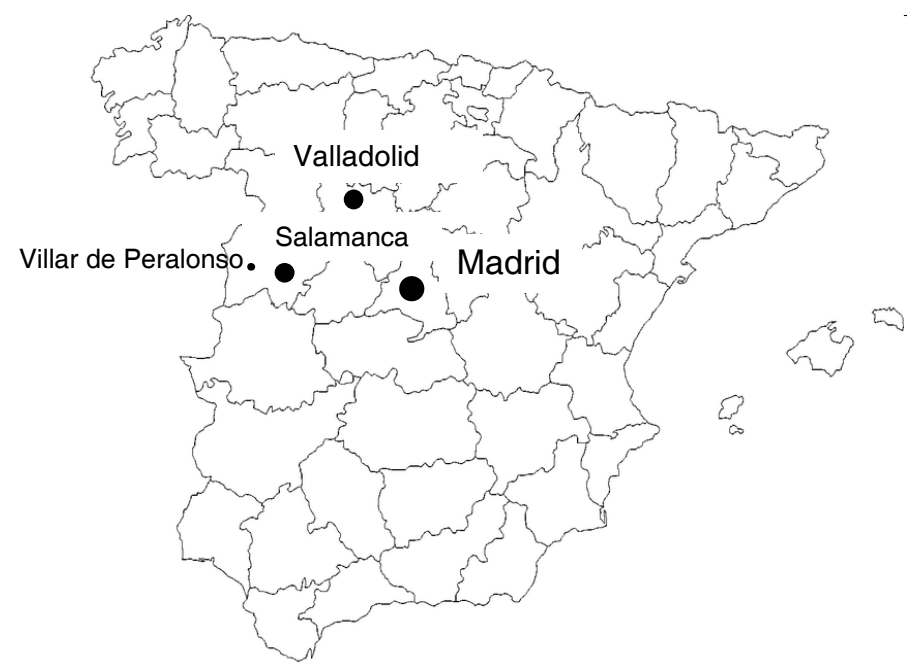

Figure 1 Map of Spain with locations indicated of the sampling sites Villar de Peralonso and Valladolid.

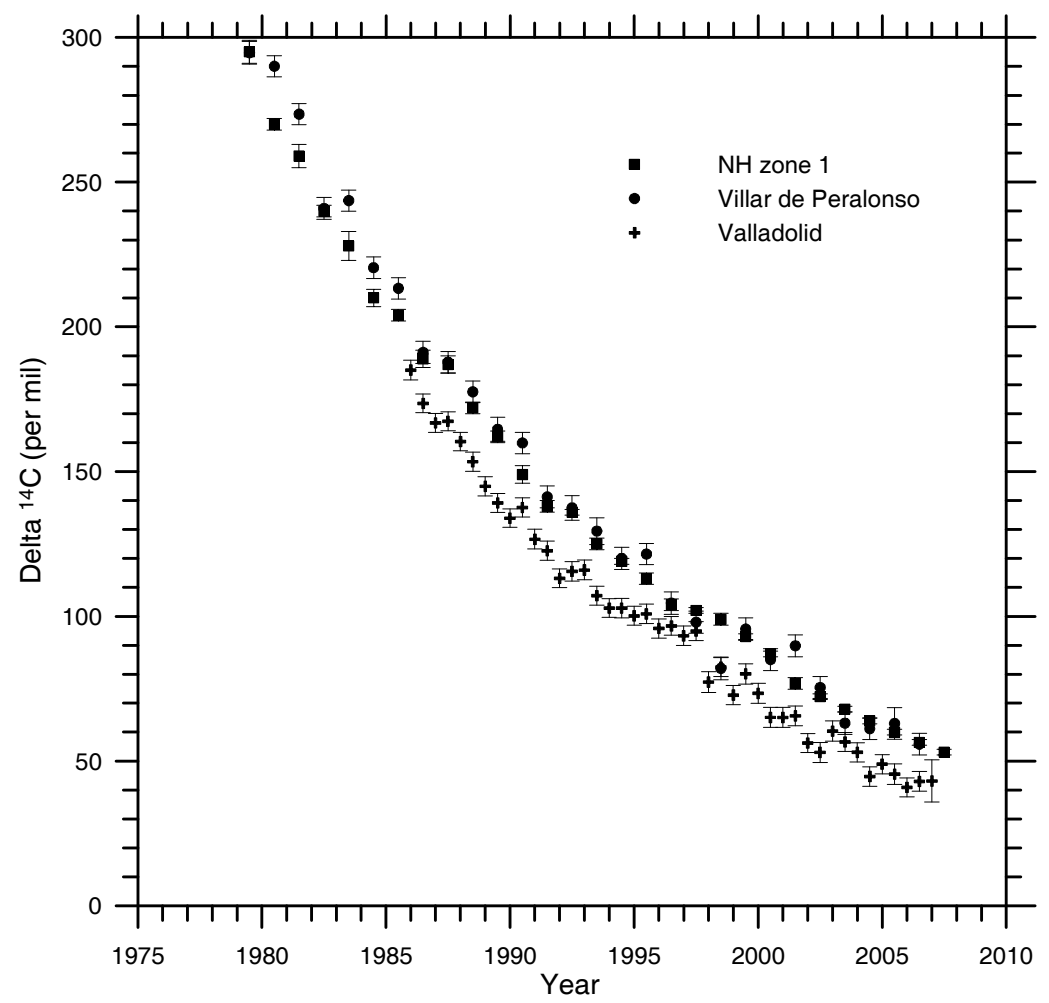

Figure 2 Radiocarbon concentration in tree rings (Pinus pinea) from Villar de Peralonso and Valladolid, Castile and Leon, Spain. Data from Villar de Peralonso and NH zone 1 (Hua and Barbetti 2004) represent ${ }^{14} \mathrm{C}$ concentration in "clean air." Data from Valladolid were originally published in Rakowski et al. (2010) and represent ${ }^{14} \mathrm{C}$ concentration in an urban area in the center of Valladolid. 


\section{Valladolid}

The city of Valladolid $\left(41^{\circ} 38^{\prime} \mathrm{N}, 4^{\circ} 43^{\prime} \mathrm{E}, 695 \mathrm{~m}\right.$ asl) is the capital of Valladolid province (Figure 1) and the autonomous community of Castile and Leon, Spain. Along with pollution stemming from urban infrastructure and vehicles, local industrial facilities in Valladolid and the surrounding area are the main sources of $\mathrm{CO}_{2}$ emissions. Sampling was done on a pine tree (Pinus pinea) growing in the historical center of the city near the Santa María La Antigua church. From each annual ring, the early- and late-wood ring was separated and $\alpha$-cellulose was extracted. These results were presented in Rakowski et al. (2010).

${ }^{14} \mathrm{C}$ concentrations in tree rings from Valladolid are presented in Figure 2, together with data from Villar de Peralonso, representing yearly average ${ }^{14} \mathrm{C}$ concentrations used as reference values. The figure shows ${ }^{14} \mathrm{C}$ concentrations in tree-ring samples (both early wood [EW] and late wood [LW]) from Valladolid, over the whole period between 1986 and 2007, are lower than in the "clean air" site in Villar de Peralonso, which is attributed to a local Suess effect.

The average temperature in Valladolid for each month of the year is higher than $0{ }^{\circ} \mathrm{C}$ (Agencia Estatal de Meterologa, www.aemet.es/es/portada), so we may assume that the growing period for a pine tree covers most the year. The average temperatures in the coldest months of the year (January and February) for the period $1971-2000$ are $4.0^{\circ} \mathrm{C}$ and $6.1^{\circ} \mathrm{C}$, respectively.

To estimate long-term changes in ${ }^{14} \mathrm{C}$ concentration, an exponential function was fitted to the results obtained for tree rings from Valladolid, giving a correlation coefficient of $r^{2}=0.984$. These analyses provide a time constant for decay of $13.0 \pm 0.2 \mathrm{yr}$ for the Valladolid tree rings, which is shorter than the $16.6 \pm 0.3 \mathrm{yr}$ for tree-ring data from Villar de Peralonso and $15.8 \pm 0.2 \mathrm{yr}$ for $\mathrm{NH}$ zone 1 data (Hua and Barbetti 2004). A linear function was fitted to the ${ }^{14} \mathrm{C}$ data for the entire period (19862007), giving a decreasing rate of $6.6 \pm 0.2 \%$ per year.

\section{FOSSIL FUEL EMISSION}

To estimate the local decrease in ${ }^{14} \mathrm{C}$ concentration due to the Suess effect, calculations were made using the relationship between carbon isotope composition and the $\mathrm{CO}_{2}$ concentration from fossil fuel combustion and the decreasing trend in ${ }^{14} \mathrm{C}$ content over time (Levin et al. 2003). To estimate the concentration of $\mathrm{CO}_{2}$ production due to fossil fuel emission, we assume that ${ }^{14} \mathrm{C}_{\text {foss }}=-1000 \%$. This simplifies the mass balance equation (Levin et al. 2003), leading to the formula:

$$
\mathrm{c}_{\text {foss }}=\mathrm{c}_{\mathrm{BG}} \frac{\Delta{ }^{14} \mathrm{C}_{\mathrm{BG}}-\Delta^{14} \mathrm{C}}{\Delta{ }^{14} \mathrm{C}_{\mathrm{BG}}+1000} \mathrm{ppmV}
$$

where $c$ is the concentration of $\mathrm{CO}_{2}(\mathrm{ppmV}),{ }^{14} \mathrm{C}$ is the ${ }^{14} \mathrm{C}$ concentration (\%), and $B G$ and foss are the background ("clean air") and fossil fuel factors, respectively.

Equation 1 was used to calculate $\mathrm{c}_{\text {foss }}$ in the city center of Valladolid. Data for ${ }^{14} \mathrm{C}_{\mathrm{BG}}$ in tree rings from the pine from Villar de Peralonso $\left({ }^{14} \mathrm{C}_{\mathrm{BG}}\right)$ represent the ${ }^{14} \mathrm{C}$ concentrations in "clean air." Seasonal average concentrations of $\mathrm{CO}_{2}$ in Schauinsland ( $\mathrm{c}_{\mathrm{BG}}$ GLOBALVIEW-CO2, 2012) represent the "natural" concentrations of this gas in "clean air" over Europe. The values of $\mathrm{CO}_{2}$ concentration derived from fossil fuel combustion $\left(\mathrm{c}_{\text {foss }}\right.$ ) have been calculated for the period 1986-2007 (Table 1 and Figure 3) based on the records of ${ }^{14} \mathrm{C}$ concentration in annual rings of the pine tree taken from the city center of Valladolid. These seasonal values of $c_{\text {foss }}$ in the early and late wood represent average concentrations of fossil $\mathrm{CO}_{2}$ in the months from January to June (early wood) and the months 


\section{${ }^{14}$ C in Annual Tree Rings from Salamanca Region}

from July to December (late wood). The long-term average value of $\mathrm{c}_{\text {foss }}$ for the period 1986-2007 is $5.4 \pm 0.3 \mathrm{ppmV}$. The seasonal values are $5.5 \pm 0.4 \mathrm{ppmV}$ (early wood) and $5.2 \pm 0.4 \mathrm{ppmV}$ (late wood), with the lowest values $1.0 \pm 1.7 \mathrm{ppmV}$ (1997, late wood) and $1.0 \pm 1.8 \mathrm{ppmV}$ (2003, early wood) and the highest $9.5 \pm 1.9 \mathrm{ppmV}$ (2004, late wood) and $7.9 \pm 1.9 \mathrm{ppmV}$ (1990, early wood).

Table 1 Radiocarbon concentration in Villar de Peralonso and Valladolid, Spain.

\begin{tabular}{llll|ll}
\hline & & \multicolumn{5}{c}{ Valladolid } \\
\cline { 2 - 6 } Year & Villar de Peralonso & \multicolumn{2}{c}{ Early wood } & \multicolumn{2}{c}{ Late wood } \\
\cline { 2 - 6 } & $\Delta^{14} \mathrm{C}(\%)$ & $\Delta^{14} \mathrm{C}(\%)$ & $\mathrm{c}_{\text {foss }}(\mathrm{ppmV})$ & $\Delta^{14} \mathrm{C}(\%)$ & $\mathrm{c}_{\text {foss }}(\mathrm{ppmV})$ \\
\hline 1979 & $294.7 \pm 3.9$ & - & - & - & - \\
1980 & $290.0 \pm 3.7$ & - & - & - & - \\
1981 & $273.5 \pm 3.7$ & - & - & - & - \\
1982 & $240.9 \pm 3.8$ & - & - & - & - \\
1983 & $243.6 \pm 3.7$ & - & - & - & - \\
1984 & $220.4 \pm 3.7$ & - & - & - & - \\
1985 & $213.3 \pm 3.7$ & - & - & - & $5.2 \pm 1.5$ \\
1986 & $191.2 \pm 3.8$ & $185.1 \pm 3.4$ & $1.8 \pm 1.5$ & $173.6 \pm 3.2$ & 5.5 \\
1987 & $187.8 \pm 3.7$ & $166.8 \pm 3.3$ & $6.2 \pm 1.5$ & $167.4 \pm 3.3$ & $6.0 \pm 1.5$ \\
1988 & $177.6 \pm 3.7$ & $160.4 \pm 3.2$ & $5.1 \pm 1.5$ & $153.4 \pm 3.3$ & $7.2 \pm 1.6$ \\
1989 & $164.6 \pm 4.1^{\mathrm{a}}$ & $144.9 \pm 3.3$ & $6.0 \pm 1.6$ & $139.2 \pm 3.3$ & $6.3 \pm 1.6$ \\
1990 & $159.9 \pm 3.7$ & $133.9 \pm 3.2$ & $7.9 \pm 1.6$ & $137.6 \pm 3.3$ & $6.8 \pm 1.6$ \\
1991 & $141.2 \pm 3.7$ & $126.6 \pm 3.4$ & $4.5 \pm 1.6$ & $122.6 \pm 3.3$ & $5.8 \pm 1.6$ \\
1992 & $137.5 \pm 4.3^{\mathrm{a}}$ & $113.2 \pm 3.3$ & $7.6 \pm 1.7$ & $115.5 \pm 3.4$ & $5.6 \pm 1.6$ \\
1993 & $129.5 \pm 4.6^{\mathrm{a}}$ & $116.0 \pm 3.4$ & $4.3 \pm 1.6$ & $107.2 \pm 3.3$ & $5.9 \pm 1.6$ \\
1994 & $120.0 \pm 3.8$ & $102.8 \pm 3.2$ & $5.5 \pm 1.6$ & $102.8 \pm 3.4$ & $5.5 \pm 1.7$ \\
1995 & $121.5 \pm 3.7$ & $100.2 \pm 3.3$ & $6.9 \pm 1.7$ & $100.9 \pm 3.3$ & $6.7 \pm 1.7$ \\
1996 & $104.6 \pm 3.9$ & $95.8 \pm 3.3$ & $2.9 \pm 1.6$ & $96.7 \pm 3.3$ & $2.6 \pm 1.6$ \\
1997 & $98.0 \pm 3.8$ & $93.3 \pm 3.4$ & $1.6 \pm 1.7$ & $94.9 \pm 3.3$ & $1.0 \pm 1.7$ \\
1998 & $95.9 \pm 3.9$ & $77.3 \pm 3.6$ & $6.3 \pm 1.8$ & $82.4 \pm 3.3$ & $3.6 \pm 1.7$ \\
1999 & $95.6 \pm 3.9$ & $72.8 \pm 3.3$ & $7.7 \pm 1.7$ & $80.1 \pm 3.5$ & $5.2 \pm 1.7$ \\
2000 & $85.0 \pm 3.8$ & $73.4 \pm 3.4$ & $5.6 \pm 1.8$ & $65.1 \pm 3.5$ & $8.4 \pm 1.8$ \\
2001 & $89.8 \pm 3.7$ & $65.1 \pm 3.4$ & $5.2 \pm 1.8$ & $65.6 \pm 3.4$ & $4.2 \pm 1.8$ \\
2002 & $75.4 \pm 3.9$ & $56.2 \pm 3.3$ & $6.7 \pm 1.8$ & $53.0 \pm 3.5$ & $7.0 \pm 1.8$ \\
2003 & $63.1 \pm 3.7$ & $60.4 \pm 3.5$ & $1.0 \pm 1.8$ & $56.6 \pm 3.3$ & $2.3 \pm 1.8$ \\
2004 & $71.8 \pm 3.7$ & $53.0 \pm 3.3$ & $6.6 \pm 1.8$ & $44.7 \pm 3.4$ & $9.5 \pm 1.9$ \\
2005 & $63.0 \pm 5.5^{\mathrm{a}}$ & $48.9 \pm 3.4$ & $5.0 \pm 1.8$ & $45.5 \pm 3.5$ & $5.6 \pm 1.9$ \\
2006 & $61.2 \pm 3.7$ & $40.9 \pm 3.3$ & $7.3 \pm 1.8$ & $43.0 \pm 3.4$ & $6.5 \pm 1.9$ \\
2007 & $55.2 \pm 5.1^{\mathrm{a}}$ & $43.1 \pm 7.3$ & $4.6 \pm 2.8$ & - & - \\
\hline
\end{tabular}

${ }^{a}$ Value calculated using exponential function fitted to the observed data.

Figure 4 shows the total annual emissions of $\mathrm{CO}_{2}$ in Spain (GLOBALVIEW-CO2, 2012). There is no significant correlation between the annual $\mathrm{c}_{\text {foss }}$ value and the annual $\mathrm{CO}_{2}$ emission $\left(r^{2}=0.003\right)$, which suggests that the important factor is the local emission of this gas. Unfortunately, there are no such records available for this location. We can only speculate on the reasons for temporal changes in annual $\mathrm{c}_{\text {foss }}$ values. One reason may be related to changes in local consumption of natural gas from surrounding households (heating systems), which depends on the weather conditions. Average temperatures in January and February for the study period vary between $1 .{ }^{\circ} \mathrm{C}(1990)$ and $6.8{ }^{\circ} \mathrm{C}$ (1988) for January and between $2.4^{\circ} \mathrm{C}(2005)$ and $8.7^{\circ} \mathrm{C}$ in February (1990; www.tiempo.com), and there is no significant correlation between $\mathrm{c}_{\text {foss }}$ values and average temperature in January 


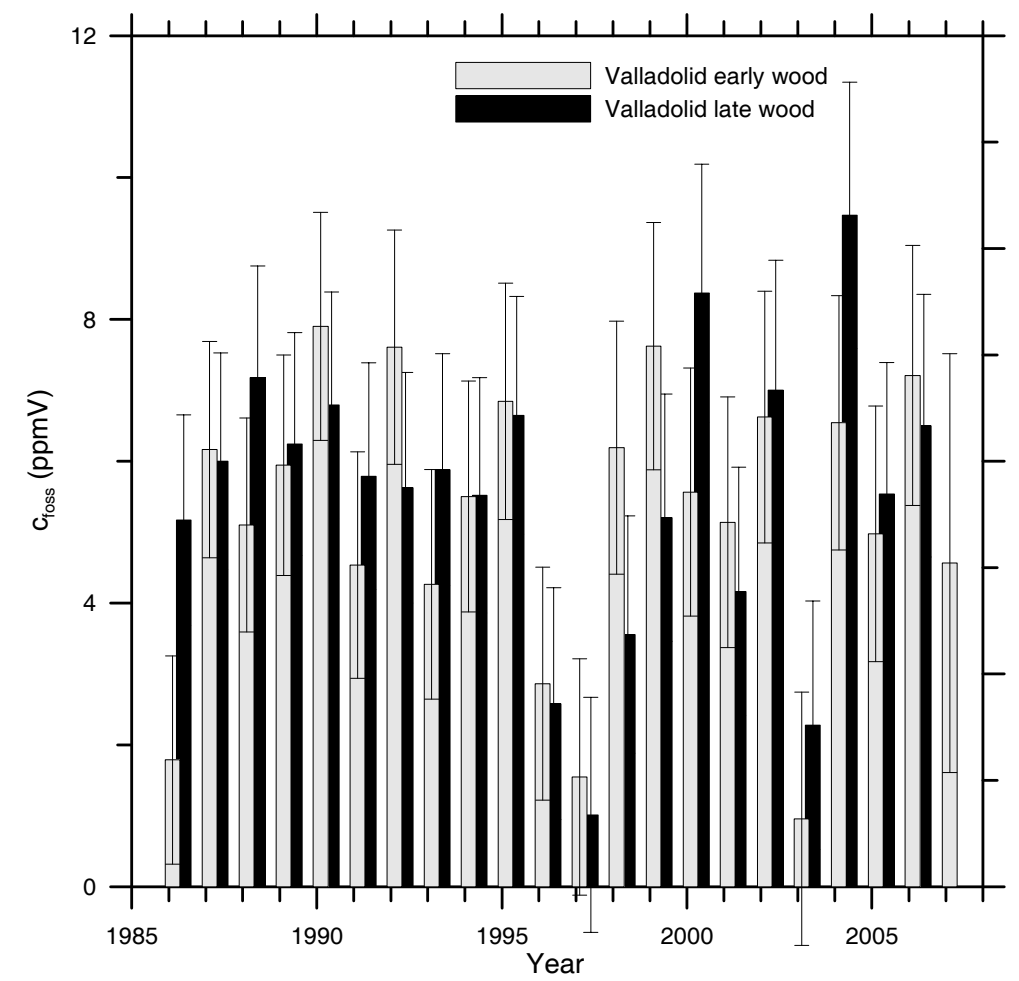

Figure $3 c_{\text {foss }}$ component in Valladolid in early (January-June) and late wood (July-December).

$\left(r^{2}=0.002\right)$ or in February $\left(r^{2}=0.031\right)$. This means that the main source of $\mathrm{CO}_{2}$ could be related to motor vehicle exhaust. For most of the study period, the average $\mathrm{c}_{\text {foss }}$ values are $\sim 5 \mathrm{ppmV}$ (Figure 3 ) with a few exceptions in which the values are lower. In this case, the lowest observed $\mathrm{c}_{\text {foss }}$ values, in 1996, 1997, and 2003 (see above), may reflect periods when the roads surrounding the tree were closed due to construction, leading to lower traffic and thus to lower emission of $\mathrm{CO}_{2}$ from fossil fuel use.

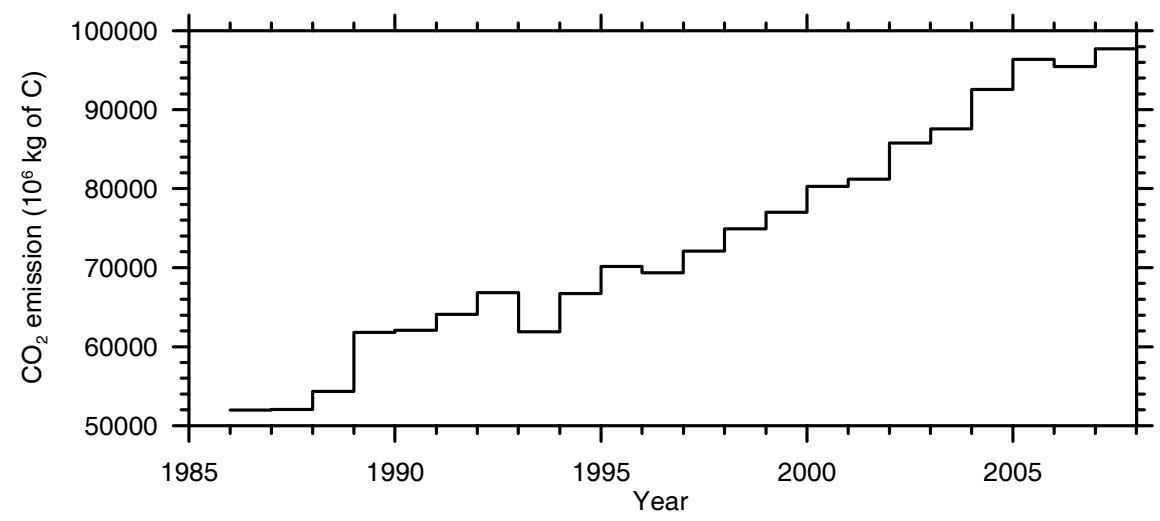

Figure 4 Total $\mathrm{CO}_{2}$ emission in Spain (GLOBALVIEW-CO2, 2012) 
${ }^{14} \mathrm{C}$ in Annual Tree Rings from Salamanca Region

\section{CONCLUSION}

The results of this investigation show that the ${ }^{14} \mathrm{C}$ concentrations in tree rings from the Villar de Peralonso area in western Spain are similar to those in "clean air" from NH zone 1 (Hua and Barbetti 2004), and could be used to calculate average seasonal $\mathrm{c}_{\text {foss }}$ values in Valladolid (Spain).

${ }^{14} \mathrm{C}$ concentrations in tree rings from Valladolid for the last $20 \mathrm{yr}$ are systematically lower than those measured in "clean air" in Villar de Peralonso because of anthropogenic $\mathrm{CO}_{2}$ emissions from fossil fuel use. From the tree-ring data, it was possible to calculate the fossil fuel component $\left(\mathrm{c}_{\text {foss }}\right)$ from the total concentration of $\mathrm{CO}_{2}$ in the city center. Results obtained show that with isotopic information recorded in tree rings, it is possible to reconstruct ${ }^{14} \mathrm{C}$ concentrations in the past, and data like this can also be used for analytical calculation. However, without information on the changes in total $\mathrm{CO}_{2}$ emission in the local area it may be difficult to identify the main sources of emission of this gas.

\section{ACKNOWLEDGMENTS}

The authors would like to express their thanks to all staff of the GADAM Excellence Centre of Silesian University of Technology, Center for Chronological Research of Nagoya University, and Leibniz Labor in Kiel for its help and creative working environment. Special thanks are directed to our Spanish colleagues, Dr Elena Charro from University of Valladolid and Dr Jose Luis Gutierrez Villanueva from University of Santander, for their contribution to this project.

\section{REFERENCES}

GLOBALVIEW-CO2. 2012. Cooperative Atmospheric Data Integration Project - Carbon Dioxide [CDROM]. NOAA CMDL, Boulder, Colorado. Also available online at http://www.esrl.noaa.gov/gmd/ ccgg/globalview/co2/co2_intro.html.

Green JW. 1963. Wood cellulose. In: Wolfrom ML, BeMiller JN, editors. Methods of Carbohydrate Chemistry: Cellulose. New York: Academic Press. p 9-21.

Gupta SK, Polach HA. 1985. Radiocarbon Dating Practices at ANU. Handbook, Radiocarbon Dating Laboratory. Research School of Pacific Studies, ANU, Canberra.

Hua Q, Barbetti M. 2004. Review of tropospheric bomb ${ }^{14} \mathrm{C}$ data for carbon cycle modeling and age calibration purposes. Radiocarbon 46(3):1273-98.

Kitagawa H, Masuzawa T, Nakamura T, Matsumoto E. 1993. A batch preparation method for graphite targets with low level background for AMS ${ }^{14} \mathrm{C}$ measurements. Radiocarbon 35(2):295-300.

Levin I, Kromer B, Schmidt M, Sartorius H. 2003. A novel approach for independent budgeting of fossil fuel $\mathrm{CO}_{2}$ over Europe by ${ }^{14} \mathrm{CO}_{2}$ observation. Geophysical Research Letters 30(23):2194, doi:10.1029/ 2003 GL018477.

McNeely R. 1994. Long-term environmental monitoring of ${ }^{14} \mathrm{C}$ levels in the Ottawa region. Environment International 20(5):675-9.

Mook WG, van der Plicht J. 1999. Reporting ${ }^{14} \mathrm{C}$ activities and concentrations. Radiocarbon 41(3):227-40.

Muraki Y, Kocharov G, Nishiyama T, Naruse Y, Murata T, Masuda K, Arslanov KhA. 1998. The new Nagoya
Radiocarbon Laboratory. Radiocarbon 40(1):177-82. Muraki Y, Masuda K, Arslanov KhA, Toyoizumi H, Kato M, Naruse Y, Nishiyama T. 2001. Measurement of radiocarbon content in leaves from some Japanese sites. Radiocarbon 42(2B):695-701.

Nakamura T, Niu E, Oda H, Ikeda A, Minami M, Takahashi H, Adachi M, Pals L, Gottdang A, Suya N. 2000. The HVEE Tandetron AMS system at Nagoya University. Nuclear Instruments and Methods in Physics Research B 172(1-4):52-7.

Pazdur A, Korput S, Fogtman M, Szczepanek M, Hałas S, Krąpiec E, Szychowska-Krąpiec E. 2005. Carbon13 in $\alpha$-cellulose of oak latewood (Jędrzejów, southern Poland) during the Maunder Minimum. Geological Quarterly 49(2):165-72.

Quarta G, Rizzo GA, D’Elia M, Calcagnile L. 2007. Spatial and temporal reconstruction of the dispersion of anthropogenic fossil $\mathrm{CO}_{2}$ by ${ }^{14} \mathrm{C}$ AMS measurement of plant material. Nuclear Instruments and Methods in Physics Research B 259(1):421-5.

Rakowski AZ, Nakamura T, Pazdur A. 2008. Variations of anthropogenic $\mathrm{CO}_{2}$ in urban area deduced by radiocarbon concentration in modern tree rings. Journal of Environmental Radioactivity 99(10):1558-65.

Rakowski AZ, Nakamura T, Pazdur A, Charo E, Gutierrez-Villanueva JL, Piotrowska N. 2010. Radiocarbon concentration in modern tree rings from Valladolid, Spain. Nuclear Instruments and Methods in Physics Research B 268(7-8):1110-2.

Rakowski AZ, Nadeau M-J, Nakamura T, Pazdur A, Pawełczyk S, Piotrowska N. 2012. Radiocarbon 


\section{A Z Rakowski et al.}

method in environmental monitoring of $\mathrm{CO}_{2}$ emission. Nuclear Instruments and Methods in Physics Research B 294:503-7.

Stuiver M, Polach HA. 1977. Discussion: reporting of ${ }^{14} \mathrm{C}$ data. Radiocarbon 19(3):355-63.
Suess HE. 1955. Radiocarbon concentration in modern wood. Science 122(3166):415-7.

World Weather Online. 2012. Spain weather averages. URL: www.worldweatheronline.com/Vitigudinoweather-averages/Castilla-y-Leon/ES.aspx. 